\title{
The Role of ERISA Preemption in Health Reform: Opportunities and Limits
}

Peter D. Jacobson

University of Michigan School of Public Health, pdj@umich.edu

This paper can be downloaded free of charge from:

http://scholarship.law.georgetown.edu/ois_papers/27 


\section{Legal Solutions in Health Reform}

The Role of ERISA

Preemption in Health

Reform: Opportunities

and Limits

Peter D. Jacobson, JD, MPH 


\section{O’Neill Institute}

for National and Global Health Law

\section{THE LINDA D. AND TIMOTHY J. O’NEILL INSTITUTE FOR NATIONAL AND GLOBAL HEALTH LAW}

AT

GEORGETOWN LAW

The O'Neill Institute for National and Global Health Law at Georgetown University is the premier center for health law, scholarship and policy. Housed at Georgetown University Law Center, in the heart of the nation's capital, the Institute has the mission to provide innovative solutions for the leading health problems in America and globally-from infectious and chronic diseases to health care financing and health systems. The Institute, a joint project of the Law Center and School of Nursing and Health Studies, also draws upon the University's considerable intellectual resources, including the School of Medicine, the Public Policy Institute, and the Kennedy Institute of Ethics.

The essential vision for the O'Neill Institute rests upon the proposition that the law has been, and will remain, a fundamental tool for solving critical health problems in our global, national, and local communities. By contributing to a more powerful and deeper understanding of the multiple ways in which law can be used to improve health, the O'Neill Institute hopes to advance scholarship, research, and teaching that will encourage key decisionmakers in the public, private, and civil society sectors to employ the law as a positive tool for enabling more people in the United States and throughout the world to lead healthier lives.

- Teaching. Georgetown is educating future generations of students who will become - upon their graduation - policymakers, health professionals, business leaders, scholars, attorneys, physicians, nurses, scientists, diplomats, judges, chief executive officers, and leaders in many other private, public, and nonprofit fields of endeavor. The O'Neill Institute helps to prepare graduates to engage in multidisciplinary conversations about national and global health care law and policy and to rigorously analyze the theoretical, philosophical, political, cultural, economic, scientific, and ethical bases for understanding and addressing health problems.

- Scholarship. O'Neill supports world-class research that is applied to urgent health problems, using a complex, comprehensive, interdisciplinary, and transnational approach to go beyond a narrow vision of health law that focuses solely on health care as an industry or as a scientific endeavor.

- Reflective Problem-Solving. For select high-priority issues, the O'Neill Institute organizes reflective problem-solving initiatives in which the Institute seeks to bridge the gap between key policymakers in the public, private, and civil society sectors and the intellectual talent and knowledge that resides in academia.

O’NEILL INSTITUTE FOR NATIONAL AND GLOBAL HEALTH LAW 


\section{OVERVIEW \\ LEGAL SOLUTIONS IN HEALTH REFORM}

The American public has increasingly identified health care as a key issue of concern. In order to address the multiple problems relating to the access and affordability of health care, President Obama and federal lawmakers across the political spectrum continue to call for major health reform. In any debate on health reform, a predictable set of complex policy, management, economic, and legal issues is likely to be raised. Due to the diverse interests involved, these issues could lead to a series of high-stakes policy debates. Therefore, it is critical that advocates of reform strategies anticipate such issues in order to decrease the likelihood that legally resolvable questions become barriers to substantive health reform. In an effort to frame and study legal challenges and solutions in advance of the heat of political debate, the O’Neill Institute for National and Global Health Law at Georgetown University and the Robert Wood Johnson Foundation have crafted the "Legal Solutions in Health Reform” project.

This project aims to identify practical, workable solutions to the kinds of legal issues that may arise in any upcoming federal health reform debate. While other academic and research organizations are exploring important policy, management, and economic questions relating to health reform, the O'Neill Institute has focused solely on the critical legal issues relating to federal health reform. The target audience includes elected officials and their staff, attorneys who work in key executive and legislative branch agencies, private industry lawyers, academic institutions, and other key players. This project attempts to pave the road towards improved health care for the nation by providing stakeholders a concise analysis of the complex legal issues relating to health reform, and a clear articulation of the range of solutions available.

\section{Legal Issues V. Policy Issues}

Among the major issues in federal health reform, there are recurring questions that are policybased and those that are legally-based. Many times questions of policy and of law overlap and cannot be considered in isolation. However, for the purpose of this project, we draw the distinction between law and policy based on the presence of clear legal permission or prohibition.

Under this distinction, policy issues include larger-scale questions such as what basic model of health reform to use, as well as more technical questions such as what threshold to use for poverty level subsidies and cost-sharing for preventive services. In contrast, legal issues are those involving constitutional, statutory, or regulatory questions such as whether the Constitution allows a certain congressional action or whether particular laws run parallel or conflict.

Based on this dividing line of clear permission or prohibition, policy questions can be framed as those beginning with, "Should we...?", and legal questions can be framed as those beginning with, "Can we...?" The focus of this paper will be the latter, broken into three particular categories: 1) "Under the Constitution, can we ever...?”; 2) "Under current statutes and regulations, can we now...?”; 3) “ Under the current regulatory scheme, how do we...?” This final set of questions tends to be mixed questions of policy, law, and good legislative drafting.

\section{Purpose and Layout of The Project}

O’NEILL INSTITUTE FOR NATIONAL AND GLOBAL HEALTH LAW

GEORGETOWN LAW | 600 NEW JERSEY AVENUE NW | WASHINGTON, DC 20001 www.oneillinstitute.org 
This project is an effort to frame and study legal challenges and solutions in advance of the heat of political debate. This effort is undertaken with the optimistic view that all legal problems addressed are either soluble or avoidable. Rather than setting up roadblocks, this project is a constructive activity, attempting to pave the road towards improved health care for the nation. Consequently, it does not attempt to create consensus solutions for the identified problems nor is it an attempt to provide a unified field theory of how to provide health insurance in America. Furthermore, this project does not attempt to choose among the currently competing proposals or make recommendations among them. Instead, it is a comprehensive project written to provide policy makers, attorneys, and other key stakeholders with a concise analysis of the complex legal issues relating to health reform and a clear articulation of the range of solutions available for resolving those questions.

\section{LEGAL ISSUES}

Based on surveys of current health policy meetings and agendas, popular and professional press, and current health reform proposals, our team formulated a list of legal issues relating to federal health reform. After much research, discussion, and expert advice and review, our initial list of over 50 legal issues was narrowed to ten. An initial framing paper was drafted which identified these ten legal issues and briefly outlined the main components of each. In May of 2008, a bipartisan consultation session was convened to provide concrete feedback on the choice and framing of the legal issues. The attendees of the consultation session included congressional staff, executive branch officials, advocates, attorneys, employers, and representatives of a wide range of interests affected by health reform. Feedback and analysis from this session further narrowed the ten issues to eight key legal issues which warranted in depth analysis of the current law.

These eight pertinent issues are truly legal in nature and must be addressed in any significant reform proposal to avoid needless debate or pitfalls as policy decisions are made. There are multiple other legal issues that will arise as the discussion evolves and, if a federal policy is adopted, the system changes. In this project, however, we have targeted the issues essential for an immediate discussion of federal health reform. 


\section{O’Neill Institute}

for National and Global Health Law

\section{LEgAL Solutions IN HEALTh REFoRM PROJECT}

JOHN T. MONAHAN, JD

Research Professor

Georgetown Health Policy Institute

Co-Director

Legal Solutions in Health Reform

JACQUELINE R. SCOTT, JD, ML

Adjunct Professor, Senior Fellow

Harrison Institute for Public Law

Georgetown Law

BENJAMIN E. BERKMAN, JD, MPH

Former Deputy Director \& Adjunct Professor

O’Neill Institute

Georgetown Law

\section{SHEILA P. BURKe, MPA, RN}

Research Professor

Georgetown Public Policy Institute

Distinguished Visitor, O’Neill Institute

Adjunct Lecturer and Senior Faculty Research

Fellow, Harvard University

John F. Kennedy School of Government

LisBeTH A. ZEgGANE

Former RWJF Project Assistant

O'Neill Institute
TIMOTHY M. WESTMORELAND, JD

Visiting Professor of Law

Georgetown Law

Co-Director

Legal Solutions in Health Reform

SARA P. HoverTer, JD, LLM

Staff Attorney, Adjunct Professor

Harrison Institute for Public Law

Georgetown Law

JACK EBELER, MPA

Distinguished Visitor, O’Neill Institute

Ebeler Consulting

SANDY H. HAN, JD, LLM

Teaching Fellow

Harrison Institute for Public Law

Georgetown Law

ELENORA E. CONNORS, JD, MPH

Fellow

O’Neill Institute

Georgetown Law

Mariesa M. Martin

RWJF Project Assistant

O'Neill Institute

Special thanks to the following individuals who contributed to the editing and production of the Legal Solutions in Health Reform Series, as well as the drafting of the Executive Summaries: Brian Bowen, Astrid Dorélien, Marissa Hornsby, Amy Killelea, Melanie MacLean, Anya Prince, and Luis Rodriguez. Also special thanks to John Kraemer for editing and production assistance. 


\section{LEGAL SOLUTIONS IN HEALTH REFORM \\ LEAD AUTHORS}

Executive Authority

Madhu Chugh, JD, MPP

Law Clerk

U.S. Court of Appeals for the D.C. Circuit

Washington, D.C.

Tax Credits for Health

Fred T. Goldberg, Jr., Esq.

Partner

Skadden, Arps, Slate, Meagher \& Flom, LLP

Washington, D.C.

\section{Insurance Exchanges}

Timothy S. Jost, JD

Robert L. Willet Family Professorship of Law

Washington \& Lee School of Law

Lexington, V.A.

Privacy and Security of Information

Deven McGraw, JD, LLM, MPH

Director, Health Privacy Project

Center for Democracy \& Technology

Washington, D.C.
Individual Mandates

Mark A. Hall, JD

Fred D. \& Elizabeth Turnpage

Professor of Law

Wake Forest University School of Law

Winston-Salem, N.C.

\section{ERISA}

Peter D. Jacobson, JD, MPH

Professor of Health Law \& Policy

Director, Center for Law, Ethics, and Health University of Michigan

School of Public Health

Ann Arbor, M.I.

Purchase of Insurance Across State Lines Stephanie Kanwit, JD

Special Counsel \& Healthcare Consultant America's Health Insurance Plans

Washington, D.C.

Insurance Discrimination Based on Health Status

Sara Rosenbaum, JD

Harold and Jane Hirsh Professor of Health

Law \& Policy

Chair, Department of Health Policy

The George Washington University School

of Public Health and Health Services

Washington, D.C. 


\section{About THE AUTHOR}

Peter D. Jacobson, JD, MPH, is Professor of Health Law and Policy, and Director, Center for Law, Ethics, and Health, at the University of Michigan, School of Public Health. He teaches courses on health law, public health law, and health care regulations. Before coming to the University of Michigan, Professor Jacobson was a senior behavioral scientist at the RAND Corporation in Santa Monica, California.

In 1995, he received an Investigator Award in Health Policy Research from the Robert Wood Johnson Foundation to examine the role of the courts in shaping health care policy. The project culminated in the publication of the book Strangers in the Night: Law and Medicine in the Managed Care Era (Oxford University Press, 2002). Jacobson co-authored a law school casebook with Lawrence O. Gostin titled Law and the Health System (Foundation Press, 2005), and is also a co-author of False Hope vs. Evidence-Based Medicine: The Story of a Failed Treatment for Breast Cancer (Oxford University Press, 2007).

Professor Jacobson's current research interests focus on the relationship between law and health care delivery, law and public health systems, public health ethics, and health care safety net services. Currently, he is the Principal Investigator (PI) on studies examining how public health practitioners define and resolve day-to-day ethical challenges, the impact of state and federal law on public health preparedness, and enhancing organizational and operational efficiencies in Michigan's health care safety net providers.

Professor Jacobson would like to thank his advisory group members: Stephanie Kanwit, JD (Special Counsel \& Healthcare Consultant for America's Health Insurance Plans), Elizabeth Leonard, JD (Associate Professor University of Kansas School of Law) and Patricia Butler, JD, $\mathrm{DrPH}$ (Health Policy Analyst) for their invaluable feedback and assistance.

O’Neill Institute for National and Global Health LaW

GeORgEtown LAW | 600 NEW JERSEy AVENUE NW | WASHINGTON, DC 20001

www.oneillinstitute.org 


\section{EXECUTIVE SUMMARY \\ Prepared by the O'Neill Institute}

\section{INTRODUCTION:}

The Employee Retirement Income Security Act (ERISA) is a federal law regulating the administration of private employer-sponsored benefits including health benefits (i.e., health insurance offered by an employer). In general, since the federal government has exercised its authority to preempt state regulation of the administration of private employer-sponsored health plans, states are blocked from enforcing laws interfering with ERISA.

As many states pursue health care reform experiments, ERISA preemption becomes relevant as a potential limit on the scope and type of reforms states are able to enact. The dominant trend in ERISA litigation has been to preempt state legislation and litigation interfering with the administration of private employer sponsored health plans, making large-scale state health care reform initiatives difficult. The purpose of this paper is to examine the trajectory of judicial interpretation of ERISA and to discuss what opportunities exist to facilitate health care initiatives given the constraints of ERISA preemption.

\section{RELEVANT LAW - ERISA PRIMER:}

\section{ERISA's Preemption Provisions}

- ERISA's preemption clause preempts all state laws that relate to an employee benefit plan.

- ERISA contains an exception to this preemption rule, referred to as the "savings clause," that allows state laws to regulate the business of insurance.

- Finally, ERISA (through the "deemer clause") prevents states from characterizing a selfinsured plan as the business of insurance.

\section{ERISA's Remedial Scheme}

- Plan participants may bring a civil action under ERISA against a plan administrator who fails to comply with a request for information about the plan, to recover claimed benefits, to enforce rights under terms of the plan, or to clarify rights for future benefits.

- A plan participant can only recover the amount of the benefits denied.

- ERISA imposes a fiduciary duty on those who make discretionary decisions on behalf of the employee benefit plan. However, courts tend to be very deferential to fiduciaries.

\section{LITIGATION TRENDS:}

ERISA litigation takes two general forms: the first involves challenges to state regulation of health plans and insurers, and the second involves challenges to state tort lawsuits for delay or denial of health care. Though the former is more directly relevant to health care reform initiatives, courts have used the same analyses in both litigation areas. While smaller-scale state reforms may survive ERISA preemption, it is an open question as to how the Supreme Court might rule on whether ERISA preempts state "pay-or-play" laws.

\section{Challenges to State Regulation of Health Plans and Insurers State Pay-or-Play Laws}

- The Fourth Circuit held that Maryland's Wal-Mart Law was preempted because it affected only one company in the state and the law effectively forced Wal-Mart to restructure its health benefit plan to increase coverage. 
- The Ninth Circuit held that a similar pay-or-play law enacted in San Francisco was not preempted by ERISA because it applied to multiple types of employers. In addition, and in part because the law applied to employers with and without ERISA plans, employers had an actual choice to either pay into county funds or offer health benefits, unlike the Maryland law.

- It is still an open question as to whether or not the pay-or-play provisions of the Massachusetts Health Care Reform Act of 2006 will be preempted.

\section{Individual Mandates}

- Individual mandates have not yet been litigated under ERISA, but Courts are unlikely to find that individual mandates bind administrators and dictate plan choices.

\section{Smaller-scale State Health Care Regulation}

- State laws of general applicability, such as a state law imposing hospital bill surcharges on commercial insurers, are not preempted because their effect on employee benefit plans is indirect and insubstantial.

- State laws that are directed at insurance and that substantially affect the pooling of risk between an insurer and insured are saved, thus not preempted. Such laws include "any willing provider" laws that prevent a health plan from excluding any health care provider who is willing and able to meet the terms and conditions of plan participation.

\section{Challenges to State Tort Lawsuits}

- State laws that offer a remedy that supplants ERISA's exclusive remedial structure, such as a breach of contract action against a managed care organization for denial of coverage or a law imposing a duty on a managed care organization to exercise ordinary care in handling coverage decisions, have generally been found to be preempted.

\section{POTENTIAL SOLUTIONS:}

The Supreme Court has repeatedly stated that if ERISA preemption is to change, it is Congress' responsibility, not the Court's, to do so. There are several ways that the federal government can act:

\section{Congressional Action}

- Enact ERISA waivers to permit state health reform experiments.

- Amend ERISA to explicitly allow state-based tort litigation against managed care organizations.

\section{Regulatory Action through Executive Authority}

- The Department of Labor (DOL) could define "plan" and "benefit" in ways that expand the relief available under ERISA's remedial scheme in regulations.

- DOL could publish guidance on valid state options under ERISA.

- DOL could amend regulations on the fiduciary duty obligations to require plan administrators to justify a benefit denial decision with evidence-based medicine.

\section{CONCLUSION:}

ERISA opinions are largely impenetrable, often leading to convoluted legal doctrine. Nobody can easily predict what will be preempted. Yet, there is a certain consistency that emerges over time-the return to preemption as the default option. Given this trend, states must tread carefully in crafting health care reform initiatives that address the crisis of the uninsured without impermissibly burdening private employers’ provision of employee benefit plans.

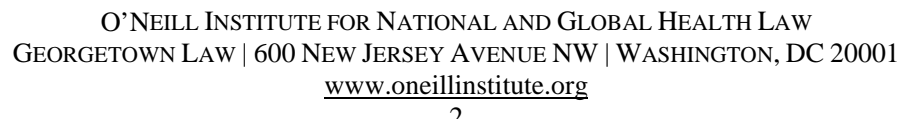




\section{Legal Solutions in Health Reform: \\ The Role of ERISA Preemption in Health Reform: Opportunities and Limits Peter D. Jacobson, JD, MPH ${ }^{1}$}

\section{Introduction: ERISA Preemption in the Context of Health Care Reform}

It should come as no surprise to any observer of health policy debates that the preemption provisions of the Employee Retirement Income Security Act (ERISA) will play a major role in determining the contours of any health reform initiative. For the past few years, many states have been aggressively pursuing health reform experiments, while congressional action has essentially been deadlocked along partisan political lines. Yet after the 2008 election results, there is reason to expect considerable congressional attention to health reform. President Obama has made health reform a priority of his administration, and several members of Congress have long been waiting for an opportunity to pursue health reform legislation.

At this point, it would be premature to speculate on the actual contours of legislation that might be enacted. But initiatives under serious consideration include "pay-or-play" measures (where employers must either provide health insurance or pay the government a defined amount per employee), and mandating that individuals purchase health insurance (similar to mandatory automobile insurance). Since similar initiatives have already been enacted at the state level, one possible scenario is that Congress may coalesce around legislation that involves some type of state-federal cooperation.

Any comprehensive state-level health reform legislation or federal legislation that relies on state activity must take into account the states' vulnerability to ERISA preemption. An important aspect of the balance between federal and state authority is the concept of preemption, which means that the federal government can preclude states from regulating a particular area. ${ }^{2}$ The rationale is to provide national uniformity in certain areas. When Congress legislates in an area and reserves power to the federal government, states may not regulate. For example, the federal government has exclusive authority for regulating nuclear power. That precludes, or preempts, any state or local attempts to regulate this field. Because ERISA preemption potentially limits the scope and type of reforms that the states might pursue, federal health reform proposals that rely on state experiments without amending ERISA could be undermined. Even if no federal legislation is enacted, ERISA preemption will remain central to the policy debate as to how far states can proceed on their own to enact comprehensive health reform laws.

This is an ironic result in two respects. For one thing, at a time when federal policymakers are encouraging state health reform initiatives, a complex federal law may imperil aggressive state health coverage experiments. In the absence of federal action, ERISA preemption may block legitimate reforms that the political system desires. For another, if state efforts are indeed blocked, pressure is likely to mount on Congress either to amend ERISA or resolve the current political deadlock. The unintended consequence of ERISA preemption, therefore, is that a statute designed to facilitate the national administration of employee health and welfare benefits is now the primary impediment to a broad range of state-based health reforms that would benefit employers and employees alike.

O’NEILl INSTITUTE FOR NATIONAL AND GLOBAL HEALTH LAW

GeORgETOWN LAW | 600 NEW JERSEY AVENUE NW | WASHINGTON, DC 20001 www.oneillinstitute.org 
The purpose of this paper is to examine the constraints of ERISA preemption in the context of potential health reform initiatives, and the opportunities that might exist to facilitate health care reform initiatives given ERISA preemption. Although ERISA would not impede comprehensive federal health reform legislation, any serious discussion of the states' role in the process needs to take ERISA preemption into account. The thesis of this paper is that the dominant trend in ERISA litigation has been to preempt challenges to state legislation and liability lawsuits against health plans. From the beginning, judicial opinions in ERISA litigation have generally favored preemption over allowing state regulation of Employee Benefit Plans (EBPs) (e.g., private employer sponsored health insurance), and preempted most lawsuits challenging a health plan's denial or delay of health care benefits. Whenever lower courts stray somewhat from preemption, the inevitable reaction at the appellate level is to restore preemption as the default option.

To provide an overview of ERISA, the next section briefly describes the salient provisions that might affect health reform legislation, followed by a summary of ERISA litigation trends. Although the primary focus in this paper is the extent to which ERISA preempts state-based insurance regulation, it is also necessary to consider patients' state medical liability litigation against health insurance plans (including managed care organizations) to understand the policy context and implications. The paper then focuses on current litigation challenging state health reform initiatives, and concludes with a discussion of potential policy solutions.

\section{An ERISA Primer}

Congress enacted ERISA in 1974 primarily to regulate pension plans, but also included health benefit plans within its scope. ${ }^{3}$ ERISA governs EBPs, including health care benefits (defined broadly to include any medical, surgical, or hospital benefits) covering approximately 65\% of the insured population. $^{4}$ ERISA's goals are to: establish uniform national standards; safeguard employee benefits from loss or abuse; and encourage employers to offer those benefits. ERISA does not mandate that employers offer benefit plans, but provides a structure for national uniformity of administration once such plans are extended. Nevertheless, ERISA has several provisions that directly affect state health reform initiatives: the preemption provisions, its limited remedial scheme, and its fiduciary duty obligation.

Many observers and stakeholders credit ERISA preemption with facilitating the growth of managed care and allowing large employers to develop national coverage arrangements for employees. The consequences of ERISA preemption lie at the heart of past congressional debates over whether proposed patients' rights legislation, if enacted, would permit patients to sue health plans for delayed or denied care, and whether the current state-based health reforms underway or under consideration can survive an ERISA preemption challenge. Throughout this discussion, it is important to keep in mind that ERISA presents a series of tradeoffs and careful balancing between protecting the interests of health plan beneficiaries (i.e., employees) and encouraging employers to adopt and fund EBPs.

\section{A. ERISA's Preemption Clause}

Traditionally, states are responsible for regulating health care delivery, and litigation against health care providers is resolved under state law. Medical liability lawsuits are rarely heard in federal courts. ERISA alters the traditional approach because it preempts state law, which means that state laws purporting to regulate health plans may not be enforced in any court. ${ }^{5}$ In this

O’NEILL INSTITUTE FOR NATIONAL AND GLOBAL HEALTH LAW

GEORGETOWN LAW | 600 NEW JERSEY AVENUE NW | WASHINGTON, DC 20001 www.oneillinstitute.org 
context, state laws include legislation and regulations, such as those mandating particular benefit coverage, and most medical liability actions targeting health plans. ERISA preempts state laws that attempt to regulate EBPs (both self-funded and fully insured) and drastically limits state medical liability lawsuits against health plans, while providing minimal federal regulation in their place. But ERISA does not prevent a state from regulating the underlying insurance coverage that an individual purchases in either the commercial market or as provided to an employer group plan. Drawing the line between the two concepts has not been easy and adds to ERISA's general complexity. The end result is that states can mandate insurance benefit coverage for non-ERISA plans, but not for an EBP.

From the beginning, courts have interpreted the preemption clause broadly to prevent enforcement of state laws ranging from laws protecting the physician-patient relationship to litigation challenging how cost containment initiatives are implemented. The courts have held that Congress intended such broad preemption of state law to allow a multistate employer to offer a single, nationally consistent plan to all its workers without the cost and inconvenience of complying with contradictory state regulations, legislation, or litigation. National uniformity conforms to congressional intent to keep the costs of administering an EBP low to encourage employers to offer health coverage. ${ }^{6}$

In assessing whether a particular state law is prohibited, courts look sequentially to each of the three parts of the preemption provision. First, courts decide whether the state law "relates to" an EBP. ${ }^{7}$ In doing so, courts consider whether the challenged law burdens the administration of plan benefits or has only a remote impact on them. Courts generally hold that ERISA preempts state laws that bind employers or plan administrators to particular benefit choices or that preclude the uniform administration of an EBP. ${ }^{8}$ For example, a state lawsuit challenging a benefit determination, such as a health plan's denial of additional hospital coverage, relates to an employer-sponsored health plan because that challenge would require the court to interpret the plan's benefits, hence binding the administrator to certain actions. But laws with only a remote or incidental effect on plan administration, such as a surcharge on hospital services, may not relate to the EBP.

A law is not preempted merely because it relates to a plan. Courts must also interpret two qualifying provisions, ERISA's “savings" and “deemer" clauses. The savings clause provides that laws regulating the business of insurance, even if they relate to an EBP, will not be preempted. Under the savings clause, states are not preempted from enacting and enforcing state laws governing the business of insurance (i.e., state regulation of health insurance), such as solvency or licensing requirements. In turn, the deemer clause qualifies the savings clause. The deemer clause prevents states from deeming (or characterizing) an ERISA-covered plan as the business of insurance. States may not characterize a self-funded plan as an insurer to circumvent the effect of the "relates to" provision.

As an example of how these terms interact, consider a state law mandating certain health insurance benefits. That law relates to an ERISA plan since it would involve the structure of plan benefits. Even though the legislation would be saved from preemption insofar as it regulates EBPs that purchase traditional insurance policies, it would still be preempted if, for instance, a state attempted to apply the statute to a self-funded EBP. Under the deemer clause, a self-funded EBP cannot be an insurer.

O’NEILL INSTITUTE FOR NATIONAL AND GLOBAL HEALTH LAW GEORGETOWN LAW | 600 NEW JERSEY AVENUE NW | WASHINGTON, DC 20001 www.oneillinstitute.org 


\section{B. ERISA's Limited Remedies}

ERISA provides some relief for injuries to health plan participants through its civil enforcement scheme. A plan participant or beneficiary may bring a civil action against an administrator who fails to comply with a request for information about the plan, to recover claimed benefits, to enforce rights under the terms of the plan, or to clarify rights to future benefits. ${ }^{9}$ A plan participant may also bring suit against a plan fiduciary who breaches any fiduciary duties, and may seek to enjoin practices which violate ERISA or the terms of the plan.

Even if victorious, a plan participant can usually only recover the amount of the benefits that should have been provided, as well as certain incidentals such as attorneys' fees. This is a decidedly more limited remedy than usually available under state law, where the patient might be able to recover damages for any economic losses, non-economic damages for pain and suffering, and possibly punitive damages, especially in cases alleging bad faith insurance denial. ${ }^{10}$ Effectively, this insulates the health plan from exposure to monetary damages, except for what it would have paid (the amount of the denied benefit) in the first place.

\section{Fiduciary Duties}

ERISA imposes a fiduciary duty on those who make discretionary decisions on behalf of the EBP. A fiduciary must discharge his or her discretionary functions "solely in the interest of the participants and beneficiaries" of the plan. ${ }^{11}$ In many, but not all cases, ${ }^{12}$ courts have held that health plans are subject to this fiduciary duty when making certain decisions, such as reviewing the appropriateness of a physician's treatment recommendations. ${ }^{13}$ On the other hand, health plans and employers are not considered fiduciaries with regard to establishing or changing the terms of the plan. Thus, the fiduciary duty extends only to decisions made once the plan is in place. ${ }^{14}$ Employers must provide whatever health benefits they promise, but need not offer plans at all and can change what they offer after giving plan beneficiaries proper notice.

Another aspect of the fiduciary duty is to preserve plan assets, meaning that the fiduciary must balance the interests of an individual beneficiary against the interests of all plan participants. In exercising the fiduciary duty, one obvious problem is that the clinical needs of one patient may conflict with the health plan's economic interests (i.e., preserving plan assets to benefit all participants). Increasingly, disappointed plan beneficiaries have sued for breach of fiduciary duty, often challenging the denial of physician-prescribed benefits, especially when there is a potential conflict of interest. ${ }^{15}$

To determine whether a health plan breached its fiduciary duty when denying plan benefits (i.e., that the denial is not "solely in the interest of the participant"), courts employ different levels of scrutiny based on the amount of discretion granted to the plan under the EBP. Generally, courts are very deferential, upholding the plan administrator as long as the plan expressly grants discretion to the plan administrator and the decision was not arbitrary and capricious. ${ }^{16}$ In most cases, courts have equated compliance with the terms of the EBP as, by definition, acting in the interests of the plan participant. As a result, the court limits its review to ensuring that the plan administrator reasonably comported with the terms of the EBP. ${ }^{17}$ By controlling the interpretation of EBP terms (including medical necessity), health plans retain power vis-a-vis physicians. But in a case where the plan profits directly from the denial, the potential conflict of

O’NEILl INSTITUTE FOR NATIONAL AND GLOBAL HEALTH LAW 
interest must be considered as perhaps the most important factor in deciding whether there was an abuse of the fiduciary's discretion. ${ }^{18}$

\section{Federal Regulations}

The Department of Labor (DOL) has jurisdiction over ERISA. For the most part, DOL has taken a hands-off approach to EBPs (focusing on pensions), limiting its regulatory oversight to some specific procedural requirements. To be sure, these procedural regulations, such as the types of information that must be provided to plan beneficiaries and participants, how claims are handled, and required reporting to DOL, are hardly trivial. But they are not the kinds of substantive regulations that are equivalent to state insurance oversight and enforcement. In essence, ERISA preemption creates a regulatory vacuum where states cannot act and there is no comparable federal regulatory presence.

\section{ERISA Litigation Trends}

To understand the nature of the ERISA preemption challenges to current state-based health reform initiatives, it is helpful to sketch the trends in ERISA litigation. Although there are numerous branches of ERISA litigation, the two that are most important for health reform are cases dealing with preemption of state tort lawsuits for delayed or denied health care, and those challenging state regulation of health plans and other health insurers. The reason why we need to look at both types of cases is that they do not operate in isolation from one another. How the courts interpret ERISA in one line of cases influences the judicial analysis of the statute in the other area. ${ }^{19}$ In this sense, both aspects are interpreted simultaneously and contribute equally to the development of legal doctrine in ERISA preemption litigation over time. Because this paper is more concerned with health reform, the subsequent analysis will focus on those cases rather than on the state tort litigation decisions.

As noted earlier, the dominant trend in ERISA litigation from the beginning has been to favor preemption over more expansive interpretations that would otherwise provide states with flexibility to oversee how employer-sponsored health plans operate. For many reasons, however, any general statement about ERISA trends is contestable. To begin with, there is little academic agreement on exactly what the cases really signify, ${ }^{20}$ and little judicial consensus on how to interpret ERISA and which lines of ERISA cases to follow. Finding coherence from the myriad of ERISA opinions is quite difficult. At best, ERISA doctrine is neither predictable nor stable; it is, rather, largely muddled and most opinions are impenetrable.

\section{A. The Early Litigation: 1983-1995}

Initial conditions matter, and early ERISA preemption rulings consistently favored a broad reading of the statute, especially the "relates to" provision. With rare exception in the early litigation, the U.S. Supreme Court broadly preempted state tort litigation and state regulations of health insurance plans. ${ }^{21}$ In these cases, the Court defined the "relates to" provision very broadly to preempt virtually any law that either refers or connects to (no matter how remotely) an administrator's benefit determination. For example, the Court preempted a state law requiring pregnancy related health benefits because it related to (i.e., burdened) the administration of an EBP (prior to Congress's enactment of the Pregnancy Discrimination Act in 1978). ${ }^{22}$ Viewed as a whole, the early rulings established the Court's approach of interpreting congressional intent as

O’NEILL INSTITUTE FOR NATIONAL AND GLOBAL HEALTH LAW

GEORGETOWN LAW | 600 NEW JERSEY AVENUE NW | WASHINGTON, DC 20001 wWw.oneillinstitute.org 
encouraging multistate employers to offer employees a single plan that could be administered nationally without the cost and inconvenience of complying with contradictory state regulations.

Deference to congressional intent meant broad preemption. ${ }^{23}$ A review of the Congressional record, however, indicates Congress' overarching purpose of ERISA was to protect plan participants and beneficiaries (i.e., employees). ${ }^{24}$ And Congress' failure to give much thought to the implications of adding health benefits to what was primarily a pension statute resulted in the Court having considerable latitude on interpreting the scope of preemption. While the broad preemption rulings were not necessarily inconsistent with the legislative history, nothing in either the language of the statute or its legislative intent required these results. ${ }^{25}$ Part of the interpretive difficulty was that the statute predated the emergence of managed care as the dominant mechanism for financing and delivering health care. At any time, of course, Congress could intervene to clarify its intent.

Despite the McCarran-Ferguson Act, which explicitly reserves insurance regulation to the states, these early rulings divested states of regulatory authority over EBPs. As a consequence, the Supreme Court uniformly favored broad preemption of state involvement over a narrower sphere allowing states some room to regulate and hold health plans accountable. Because ERISA provides no substantive terms of its own and DOL as the regulatory agency has eschewed substantive regulation of EBPs, the oft-noted regulatory vacuum emerged.

Aside from the doctrinal consequences, the decisions themselves are basically impenetrable. Neither lower court judges nor academics could easily understand and apply the rulings in subsequent cases. Even Supreme Court judges admitted the muddle that their rulings created. For instance, the committed textualist Justice Anonin Scalia subsequently concluded that “Applying the 'relate to' provision according to its terms was a project doomed to failure, since, as many a curbstone philosopher has observed, everything is related to everything else.”26 Notwithstanding this admonition, neither the Court nor Congress reconsidered the doctrinal pedestal of preemption.

\section{B. Departures From Preemption: 1995-2003}

State Insurance Regulations. The first departure from a stringent preemption analysis came in 1995 with the case of New York State Conference of Blue Cross and Blue Shield Plans $v$. Travelers Insurance Co., ${ }^{27}$ where the Court signaled that state laws having only an indirect economic connection to EBPs would not be preempted. In this case, New York State imposed hospital bill surcharges on all commercial insurers other than the Blues. The Court ruled that the surcharge was a general health regulation that had only an indirect effect on EBPs, and did not bind plan administrators to any particular benefit choice. After Travelers, courts have been willing to uphold state health insurance regulations against an ERISA preemption challenge where the legislation has only an indirect effect on an EBP. In fact, as discussed below, applying the direct-indirect analysis to current state health reform legislation is one key in determining whether state reform initiatives will survive an ERISA preemption challenge.

Two subsequent Supreme Court rulings on state regulation of health plans also seemed to indicate a judicial willingness to reexamine the conceptual basis of ERISA preemption doctrine. In the 2002 case of Rush Prudential HMO v. Moran, ${ }^{28}$ the Court expanded a state's ability to

O’NEILl INSTITUTE FOR NATIONAL AND GLOBAL HEALTH LAW

GEORGETOWN LAW | 600 NEW JERSEY AVENUE NW | WASHINGTON, DC 20001 www.oneillinstitute.org 
require independent medical review (IMR) of specific health plan coverage denials. The health plan refused to cover the treating physician's non-standard treatment recommendation because it was not medically necessary. Relying on Illinois state law, Moran requested an independent medical review of her claim, which the insurer rejected. Over a vigorous dissent, the majority ruled that the Illinois law did not impose a new obligation or remedy, but instead resembled a second opinion. Therefore, IMR was saved from preemption as a legitimate state-based insurance regulation that will cause only minimal administrative burdens. To the dissent, a statemandated IMR should have been preempted because it altered the remedies available under ERISA's exclusive remedial scheme and hence interfered with the national administration of EBPs.

In 2003, the Supreme Court further deferred to state legislation under ERISA's savings provision. In Kentucky Association of Health Plans, Inc. v. Miller, ${ }^{29}$ the Court upheld Kentucky's any willing provider (AWP) law against an ERISA preemption challenge. (AWP laws prevent a health plan from excluding any medical provider who is willing and able to meet the terms and conditions of plan participation.) ${ }^{30}$ Relying on the Moran case, the Court ruled that AWP laws were saved from ERISA preemption as being specifically directed toward the insurance industry, even if they placed limits on other sectors (in this instance, on physicians). Recognizing that its prior cases failed to provide the lower courts with clear guidance, the Court redefined a two-part savings clause to determine when a state law will be deemed to regulate insurance: "First, the state law must be specifically be directed toward entities engaged in insurance. Second,...the state law must substantially affect the risk pooling arrangement between the insurer and the insured." Because the AWP law at issue altered the scope of bargaining between providers and insurers, the Court held that the law met the risk-pooling aspect of the two-part test.

Taken together, the Moran and Miller cases potentially provide greater leeway for states to regulate health insurance arrangements. Along with the direct/indirect analysis in Travelers, these cases provide the analytical framework for determining whether the current state health reform initiatives can survive an ERISA preemption challenge.

State Tort Litigation. Another case in 1995, Dukes v. U.S. Healthcare, Inc., ${ }^{31}$ opened an even wider attack on ERISA preemption. The plaintiffs claimed damages in state court under theories of direct and vicarious liability for injuries arising while being treated at a U.S. Healthcare HMO. When Dukes was decided, courts had consistently held that challenges to benefit coverage decisions, including delayed or denied care resulting from cost containment initiatives, were preempted as involving the interpretation of plan benefits. Dukes established the principle that challenges to the technical quality of care (i.e., treatment claims against managed-care organizations for their role in substandard clinical care) do not involve the administration of plan benefits and will not be preempted, allowing state courts to resolve the litigation.

In 2000, the U.S. Supreme Court attempted to clarify its view of the treatment-coverage distinction in Pegram v. Herdrich. ${ }^{32}$ In this case, Pegram asserted that her insurance plan's financial incentives for physicians led her doctor to delay an abdominal ultrasound. During the delay, her appendix ruptured, resulting in peritonitis. After the lower court held that ERISA preempted this claim, she reframed the litigation as a breach of fiduciary duty. The Supreme Court rejected the fiduciary duty claim as well, but left open the possibility that the Court accepted the treatment-coverage distinction as a basis for avoiding ERISA preemption. But the

O’NEILl INSTITUTE FOR NATIONAL AND GLOBAL HEALTH LAW

GEORGETOWN LAW | 600 NEW JERSEY AVENUE NW | WASHINGTON, DC 20001 www.oneillinstitute.org 
Court's language was ambiguous as to the kinds of mixed treatment and coverage decisions (i.e., those instances raising both coverage and treatment aspects) that should be subject to state law. ${ }^{33}$

\section{Preemption Redux: 2004-2008}

The viability of state tort action against health plans did not last long. In Aetna Health Inc. v. Davila, ${ }^{34}$ the Court clarified that mixed treatment-coverage cases (arguably the most contentious and numerous issues likely to be challenged), would indeed be preempted, holding that ERISA preempts a Texas law imposing a duty to exercise ordinary care in handling benefit coverage decisions. The Davila case makes a swift retreat from the expectation that Pegram supported the treatment-coverage distinction. Equally important, the Court refused to extend its rulings in the Miller and Moran cases. Without an extended analysis, the majority opinion rejected the claim that the Texas law should be saved from preemption as regulating insurance. The Court simply stated that the Texas law provided a claim for benefits outside of ERISA's remedial scheme, but did not disclose its reasoning for why the Texas law differed from the laws considered in Miller and Moran.

Lower Court Interpretations of Davila, Miller, and Moran. The Davila decision is not the Supreme Court's most recent pronouncement on ERISA, but it is an important one for health reform proposals. ${ }^{35}$ Along with the Miller and Moran cases, how the lower courts interpret Davila will clarify the extent to which state health reform legislation survives an ERISA preemption challenge.

Citing Davila, lower courts have limited the Miller case in claims for reimbursement under state insurance laws. Despite the Miller decision upholding AWP laws, courts have read Davila as curbing the remedies that providers can seek when insurance companies violate these laws. ${ }^{36}$ In decisions interpreting state regulations aimed at expanding health coverage for the uninsured, courts have interpreted the savings clause test articulated in Miller fairly narrowly and have used the test to preempt smaller-scale state laws purportedly aimed at the insurance industry. Similarly, courts have refused to use the Miller test to uphold large-scale state health care reform initiatives. Lower court cases that have interpreted Rush Prudential and Miller have focused on the risk-pooling prong of the new test articulated in Miller to preempt laws that do not substantially affect the transfer of risk. ${ }^{37}$ At the same time, courts have upheld state laws where they satisfy Miller's risk-pooling test, such as rules resulting in insurers paying for more claims

and incurring larger risks or altering the scope of bargains between insurers and insureds. ${ }^{38}$

\section{Interpretations of State Health Reform Legislation}

The central question on the health policy agenda right now is whether ERISA will preempt state health reform initiatives. For our purposes, I will focus on what I expect will be the two key preemption issues to address- “pay-or-play” systems and individual mandates. ${ }^{39}$ The leading example of state-based health reform legislation is the much-discussed Massachusetts plan enacted in 2006.

The Massachusetts approach combines individual and employer mandates with government subsidies. By far the most controversial and landmark aspect of the legislation is the individual mandate, which places responsibility on the individual to obtain health insurance. If an individual can afford insurance and chooses not to purchase it, he or she can be fined.

O’NEILl INSTitute FOR NATIONAL AND GLOBAL HEALTH LAW

GEORGETOWN LAW | 600 NEW JERSEY AVENUE NW | WASHINGTON, DC 20001 www.oneillinstitute.org 
Employers with more than ten employees are required to make a fair and reasonable contribution to workers' health insurance coverage or else be subject to a \$295 assessment per employee. The assessment fee is intended as an incentive to offer insurance.

One of the main aspects of the Massachusetts reform is The Connector, which allows groups to purchase insurance and ensures insurance portability from job to job. The Connector acts as a facilitator between individuals and small businesses and private insurance plans to ensure that these plans are of high value and good quality.

To fund the program, the plan redistributes existing funding, including Medicaid payments for safety net providers and the uncompensated care pool. New funding comes from employer contributions and general fund revenues. The Commonwealth Care Health Insurance Plan provides subsidized health insurance for households with income up to 300\% of the federal poverty level.

Pay-or-Play. Somewhat surprisingly, there has been no ERISA challenge to the Massachusetts law. Since then, other states and municipalities have enacted variations of the Massachusetts law that have resulted in ERISA preemption litigation. Already, there are three appellate decisions (discussed below) and several law review commentaries analyzing states' pay-or-play health reform initiatives. Two of the three cases ruled that ERISA preempted the legislation, while the third overturned the lower's court's preemption decision. Although the specifics differ across the states, the essential organizing principle of current state health reform initiatives is that employers must either spend a certain amount on employee health care or pay a specified fee (i.e., a tax or assessment) to the state in lieu of providing coverage.

Maryland's Fair Share Act required employers that employed more than 10,000 workers to spend at least $8 \%$ of their total payroll on employees' health care or spend at least $8 \%$ of total payroll on employees' health care costs. Otherwise, employers were required to pay the difference between their spending and 8\% of total payroll to Maryland's Medicaid fund. The law was soon referred to as the Wal-Mart law because it only affected one company. In Retail Industry Leaders Association v. Fielder, ${ }^{40}$ the court ruled that ERISA preempted the Act because it interfered with plan administration. By forcing the employer to restructure its plan to offer a state-imposed minimum level of health benefits, the statute impermissibly related to ERISA.

Suffolk County, New York, enacted similar legislation which also effectively only applied to Wal-Mart. Under the Suffolk County law, non-unionized retailers were required to spend the health cost rate amount on health benefits of each employee for each hour worked regardless of their full or part-time status. In the alternative, employers could make a lump sum payment to a community health center equal to the number of hours worked by employees multiplied by the public health cost rate. In Retail Industry Leaders Association v. Suffolk County, ${ }^{41}$ the court ruled that ERISA preempted the legislation. As in the Maryland case, the court determined that the legislation did not offer any real choice to employers other than to restructure its benefits plans. The interference with the administration of an employer-sponsored ERISA plan impermissibly related to ERISA.

San Francisco enacted an ordinance requiring private employers with 20 or more full time employees (FTEs) and non-profits with 50 or more FTEs to make minimum health care expenditures for their employees. The ordinance defines health care expenditures as direct

O’NEILl INSTITUTE FOR NATIONAL AND GLOBAL HEALTH LAW

GEORGETOWN LAW | 600 NEW JERSEY AVENUE NW | WASHINGTON, DC 20001 www.oneillinstitute.org 
contributions to the employee, reimbursement for health services, or payments to the City to be used on behalf of their covered employees. Under the ordinance, if the employer fails to make the required expenditure on behalf of its employees, it must make payments directly to the City. The ordinance is designed to provide access to care for uninsured adults living in San Francisco who do not qualify for coverage under Medicaid. In contrast to the above two cases, the Ninth Circuit Court of Appeals in Golden Gate Restaurant Association v. City and County of San Francisco $^{42}$ ruled that ERISA does not preempt the ordinance.

The Ninth Circuit found that the ordinance does not regulate benefits or charges for benefits provided by ERISA plans, stating that: "First, the Ordinance does not require employers to establish their own ERISA plans or to make any changes to any existing ERISA plans....Second, the Ordinance is not concerned with the nature of the health care benefits an employer provides its employees." 43 Most importantly, the court also found that the ordinance does not bind ERISA administrators to a particular choice of rules for determining plan eligibility or entitlement to particular benefits. Relying on Travelers, the court instead concluded that the ordinance does not relate to an ERISA plan. ${ }^{44}$ With regard to the Fielder case, the Ninth Circuit argued that the two cases are compatible because Maryland left employers without real options, writing, "[i]n stark contrast to the Maryland law in Fielder, the City-payment option offers employers a meaningful alternative that allows them to preserve the existing structure of their ERISA plans." 45

What accounts for the different case outcomes? In two major areas, San Francisco's law is distinguishable from Maryland's, which may account for the different judicial opinions. First, the San Francisco law applies to a range of employers, and it is akin to a law of general applicability rather than a law directed specifically at an EBP. Second, the options given to employers under the San Francisco law represent real choices (i.e., tangible benefits to employees compared to Maryland less practical alternatives) in the marketplace rather than a forced choice between restructuring ERISA plans or being out of compliance with ERISA. (For a comparison of the Maryland and San Francisco laws, see Appendix A.)

An important difference between the San Francisco law and the Maryland law is that the San Francisco law, at least ostensibly, applies to employers with or without ERISA plans, and is able to function without the existence of such plans. By contrast, the Maryland law was designed to apply to one employer in the state, Wal-Mart. In its decision preempting the Maryland law, the Fourth Circuit paid special attention to this fact. Thus, Maryland's law amounted to a direct regulation on ERISA plans rather than a revenue statute of general applicability. To avoid ERISA preemption, laws that are of general applicability to all insurers may escape direct regulation of or reference to ERISA.

What are the implications for pay-or-play laws? Despite the Ninth Circuit's statement that its opinion does not indicate a split in the federal courts, it seems likely that many observers will reach a different conclusion. If so, the apparent split may hasten Supreme Court review. When combined with the important public policy implications of pay-or-play laws, there is a good chance that the Supreme Court will accept the inevitable appeal of the San Francisco law. In the meantime, lower courts will continue to struggle with the preemption analysis and will likely reach contradictory results. Until the Supreme Court clarifies whether ERISA preempts pay-orplay laws, state and local health reform efforts will remain in ERISA limbo (otherwise known as purgatory).

O’NEILl INSTITUTE FOR NATIONAL AND GLOBAL HEALTH LAW GEORGETOWN LAW | 600 NEW JERSEY AVENUE NW | WASHINGTON, DC 20001 www.oneillinstitute.org 
As with the courts, health law commentators are split on whether pay-or-play laws are likely to survive an ERISA preemption challenge. While the weight of the commentary suggests that these laws will be preempted, that assessment is not unanimous. Most of those concluding that pay-or-play laws will be preempted include such commentators as Edward Zelinsky, Kathlynn Polvino, Jon Shimabukuro and Jennifer Staman, who largely adopt the Fourth Circuit's "relate to” analysis. Amy Monahan largely agrees, but indicates that Massachusetts’s “soft” pay-or-play law may offer the courts a way of avoiding preemption without burdening plan administration. In contrast, Pat Butler (along with Catherine Fisk and Michael Oswalt) argues that "ERISA should not preempt a well-designed pay-or-play law that offers a dollar-for-dollar credit for employer health care spending because, under the reasoning of the Travelers case, it does not interfere with ERISA plan administration choices." 46 This quote captures the essence of what is likely to be the crux of the argument: if the Supreme Court follows the Travelers line of cases, pay-or-play laws could survive. But if the Court reverts to the mean of preemption, as I expect, the laws will be preempted.

Individual Mandates. Unlike pay-or-play, the issue of whether ERISA might preempt laws that would mandate individuals to purchase health insurance (similar to mandatory automobile insurance coverage) has received considerably less attention. As far I can tell, the issue has not yet been litigated. Zelinsky has published an extensive analysis of the issue, concluding that the Massachusetts law (currently the most comprehensive individual health insurance mandate) "is the kind of mandated benefit structure that remains ERISA preempted under Travelers."47

Zelinsky argues that the individual mandate is not part of a general insurance regulatory scheme that effectively imposes a floor on what benefits plan administrators will be able to offer in Massachusetts. Thus, individual mandates bind plan administrators. Zelinsky argues that the statute dictates plan choices, and dismisses the argument that the Travelers line of cases saves the regulation from preemption because individual mandates only have an indirect effect on EBPs. $^{48}$ Zelinsky notes that Fielder rejected a similar analysis in the Maryland pay-or-play decision (though not specifically referring to an individual mandate).

Without belaboring the point, I disagree with Zelinsky's analysis on two grounds. First, the mandate goes to individuals, not to any EBP. Indeed, Butler goes further to argue that an individual mandate does not constitute insurance regulation under the savings clause because it is directed to individuals, not insurers, under the Miller test discussed earlier. ${ }^{49}$ If there is a burden, it falls on the individual to meet the expected benefits floor or the employer to keep track of expenditures made to meet the employer's obligation. Nothing in the law requires an administrator to adjust its benefit package. Under the Ninth Circuit's analysis in Golden Gate Restaurant Association, the individual mandate would not constitute an EBP because the city establishes and maintains the mandate. Since the EBP is not required to establish or administer insurance benefits under the mandate, the ordinance does not establish or maintain an ERISA plan. $^{50}$ Second, under Travelers, as Monahan observes, the individual mandate has such a tangential relationship to an EBP that an ERISA preemption challenge would be unlikely to succeed. ${ }^{51}$ At best, the administrative burden is likely to be minimal.

In this context, it is worth noting (at least for analytical, if not necessarily legal, import) that the first prong of DOL's safe harbor for determining when a health plan does not constitute an ERISA plan is that no contributions are made by an employer or employee organization. ${ }^{52}$ In

O’NEILl INSTITUTE FOR NATIONAL AND GLOBAL HEALTH LAW

GEORGETOWN LAW | 600 NEW JERSEY AVENUE NW | WASHINGTON, DC 20001 www.oneillinstitute.org 
any event, individual mandates appear to be insurance regulations of general applicability - to all persons residing in the state-that should be saved from ERISA preemption as legitimate state regulation of insurance. An individual mandate may or may not be desirable health policy, but if enacted, the mandate should survive an ERISA preemption challenge.

Summary. At this point, it is anybody's guess how the Supreme Court might rule on whether ERISA preempts pay-or-play systems or how the lower courts would examine ERISA preemption challenges to individual mandates. Small scale reforms will likely survive because they are unlikely to burden EBPs, but will hardly address the real problems facing the health care system. Unfortunately, the kinds of large scale reforms that are desperately needed are likely to be preempted because, almost by definition, they must bind administrators to be successful. Accordingly, I anticipate that pay-or-play systems will not survive an ERISA preemption challenge, while individual mandates will not be preempted. In short, the courts are unlikely to absolve Congress from amending ERISA to permit state health reform experiments to proceed on a sufficient scale.

\section{Potential Solutions}

Before considering potential solutions, I should add a few words about ERISA in the context of federalism and separation of powers. ${ }^{53}$ ERISA is a window through which health policy over the past 20 years or so can be observed. As a philosophical matter, recent Supreme Court doctrine, particularly in ERISA preemption cases, is based on the doctrine of separation of powers. One of the principal interpretive tenets or norms repeatedly stated by the current Supreme Court is that social policy should be made by the elected representatives, not by the courts. The opinions considered above consistently observe that if ERISA preemption is to change, it is Congress's responsibility, not the Supreme Court's, to do so. In strongly deferring to Congress, the Court has sent an unmistakable signal that it does not view its mandate as alleviating market or legislative deficiencies.

An important corollary doctrine about the structure of government is federalism - the question of whether power resides with the states or with the federal government. This debate goes back to the earliest days of the republic, with the federalists, led by Alexander Hamilton, arguing for a strong central government, while the Jeffersonians argued for greater state sovereignty. From the New Deal through the early 1980s, Supreme Court rulings generally favored the federal government and expanded the reach of federal legislation. Since then, that approach has been reversed, with the Court generally deferring to the states and constricting Congress's legislative authority under the Commerce Clause. ${ }^{54}$

\section{A. Congressional Action}

During the mid to late 1990s, one of the most contentious health policy debates was over patients' rights, and whether to amend ERISA to permit state-based tort litigation against MCOs. Since 2001 this issue has faded into the background. If the historical trends described earlier are accurate, attempts to amend ERISA are likely to reemerge as a salient health policy issue. Only this time, the primary focus will be on amending ERISA to permit broader state health reform initiatives, with patients' rights as a secondary consideration.

O’NEILl INSTITUTE FOR NATIONAL AND GLOBAL HEALTH LAW

GEORGETOWN LAW | 600 NEW JERSEY AVENUE NW | WASHINGTON, DC 20001 www.oneillinstitute.org 
In theory, amending ERISA preemption would be the easiest way to provide states with needed flexibility to enact health reform proposals. In practice, there is still likely to be considerable congressional opposition to any weakening of ERISA preemption. But with a new administration and, more importantly, with large employers perhaps more desperate to ease their health insurance costs, congressional action may be possible.

One consideration is whether Congress could amend ERISA in a way to permit state reforms without opening EBPs to excessive regulatory scrutiny generally. That is, the attempt to allow states greater freedom to pursue a variety of health reform experiments may have the unintended consequence of allowing more expansive state legislative oversight of EBPs. At a minimum, Congress could consider enacting ERISA waivers to permit state health reform experiments to proceed without worrying about a disruptive ERISA preemption challenge. ${ }^{55}$

\section{B. Regulatory Action}

Absent amending ERISA, the Obama administration could devise regulatory strategies to mitigate some aspects of ERISA preemption and to facilitate state health reform initiatives. One alternative suggested in Davila's concurring opinion leaves considerable room for a regulatory response:

The Government notes a potential amelioration. Recognizing that "this Court has construed Section 502(a)(3) not to authorize an award of money damages against a non-fiduciary," the Government suggests that the Act, as currently written and interpreted, may "allow at least some forms of 'make-whole' relief against a breaching fiduciary in light of the general availability of such relief in equity at the time of the divided bench."...[T]he Government's suggestion may indicate an effective remedy others similarly circumstanced might fruitfully pursue.

As noted, most of the DOL's regulatory actions have been on the pension side, and it has not acted to fill the vacuum on the health care benefits issues. Unlike antitrust, where the judicial and regulatory branches interact—sometimes uneasily - to form antitrust policy, the courts have acted exclusively to shape ERISA preemption doctrine. But DOL could issue regulations that would simultaneously protect patients and plans. Taking an aggressive approach, DOL could define two of the key ERISA terms that courts or legislation has not defined-cplan" and "benefit" - to alleviate the rigidity of ERISA preemption. Is benefit the payment of money, the goods, services the insurance purchases (i.e., medical care) or membership in an MCO? ${ }^{56} \mathrm{~A}$ major flaw in ERISA preemption is the limited damages available if a case is removed to federal court (i.e., patients can only recover the amount of the benefit). To correct that deficiency, DOL might define benefit to include reasonable economic and noneconomic damages. For instance, DOL could develop a schedule of damages to include the cost of making the patient whole, along with lost wages and pain and suffering.

Similarly, several observers have noted that ERISA does not define a health plan, ${ }^{57}$ and the courts have only said that a plan is not the equivalent of the benefits themselves. ${ }^{58}$ For reasons that are not obvious, courts have ruled that MCOs are included in the definition of plan, but not physicians. The result has been to preempt MCOs from state tort liability while leaving physicians exposed to full liability when they may not actually control resource allocation decisions. $^{59}$ Because the statutory definition of plan is somewhat tautological, ${ }^{60}$ nothing

O’NEILl INSTITUTE FOR NATIONAL AND GLOBAL HEALTH LAW 
prevents DOL from issuing a regulation that clarifies the meaning of these two terms and establishes that ERISA was not intended to "govern the relationships between employees and third parties, such as MCOs.”61

In terms of the current state health reform legislation, DOL could issue a regulation that sets the contours of how far states could proceed before implicating ERISA preemption. The mechanism for this would be through an interpretation of the savings clause. For example, DOL could adopt the direct/indirect analysis in the Travelers case and provide potential scenarios where a law would be within the scope of the savings clause. Other governmental agencies, particularly the Department of Justice/Federal Trade Commission's health antitrust guidelines, have used a similar strategy. Likewise, the key judicial consideration in the state reform legislation enacted so far is the dispute over what constitutes other legitimate compliance options in a pay-or-play system. It would be an appropriate regulatory interpretation for DOL to outline valid state options that would be saved from preemption.

Beyond the substantive regulations DOL might consider, the agency could adopt procedural regulations that would facilitate the implementation of health reform initiatives. For instance, DOL could place the burden of justifying regulations of EBPs on the states. DOL could outline what it considers to be the appropriate balance between flexible state health reforms and excessive regulation of EBPs. As long as states operate within the safe harbor, DOL would support the reform. If states go beyond the safe harbor, states could seek a waiver from DOL to continue the experiment.

As to whether courts would uphold these regulations, as a matter of the separation of powers, it would certainly be preferable for Congress to define these terms. Absent that, it would be an appropriate exercise of regulatory discretion to address terms that neither the Court nor Congress has defined. The health insurance industry would undoubtedly contest any regulations that weakened the current force of ERISA preemption. Since these regulations complement rather than undermine ERISA preemption, courts should defer to DOL's expertise. Whether these or similar regulations would result in dramatically different legal doctrine remains to be seen. For instance, courts might balk at any expanded remedy as violating ERISA's exclusive remedial structure. In any event, it will be difficult for regulators to overcome 25 years of judicial doctrine. Suffice it to say that new regulations might provide state legislators with a more level playing field. In particular, new regulations would impose some needed regulatory oversight of plan administrators, along with the accountability that is presently lacking.

\section{Conclusion}

Regardless of what the options were at the outset of judicial consideration of ERISA preemption, the broad initial preemption rulings set the tone and scope of ERISA doctrine that continues to this day. Yet if the analysis in this paper is correct, there is a certain consistency that emerges over time- the return to preemption as the default option. If that trend holds, state-based health reform initiatives could be blocked if challenged.

It is entirely possible that my analysis imposes more of a narrative arc to ERISA interpretation and litigation than it deserves. ${ }^{62}$ Other commentators may well argue that there are too many exceptions to justify a "regression to the mean" trajectory. Admittedly, I have not undertaken an adequate empirical analysis to determine whether the analytical frame I have sketched would fit

O’NEILl INSTITUTE FOR NATIONAL AND GLOBAL HEALTH LAW

GEORGETOWN LAW | 600 NEW JERSEY AVENUE NW | WASHINGTON, DC 20001 www.oneillinstitute.org 
the data. As the split among commentators noted throughout suggests, interpreting ERISA litigation trends is highly subjective. There is little clarity as to how ERISA will be interpreted in future cases, and little agreement among commentators as to why ERISA should be interpreted one way or the other.

Part of this uncertainty resides in a statute that is poorly and ambiguously drafted, and largely applicable to pension plans rather than the way health care is now organized and delivered. Congress has refused to amend ERISA, and the Department of Labor has generally refused to regulate it. The time has come for a new approach-one that facilitates reform instead of impeding it. 
APPENDIX A

Comparison of the Maryland and San Francisco "Pay or Play" Laws

\begin{tabular}{|c|c|c|}
\hline & Maryland (Wal-Mart) Law & San Francisco Law \\
\hline $\begin{array}{l}\text { What are the } \\
\text { main } \\
\text { provisions? }\end{array}$ & $\begin{array}{l}\text { Covered employers are required to spend at } \\
\text { least } 8 \% \text { of their payroll on "health } \\
\text { insurance costs." If the employer fails to } \\
\text { spend the required amount, the law requires } \\
\text { the employer to pay the difference between } \\
\text { what the employer spent on health insurance } \\
\text { costs and the } 8 \% \text { requirement into the } \\
\text { Maryland Fair Share Health Care Fund. } \\
\text { The Fund was to help finance Maryland's } \\
\text { Medicaid program. }\end{array}$ & $\begin{array}{l}\text { Covered employers are required to } \\
\text { make minimum "health care } \\
\text { expenditures" ranging from } \$ 1.17 \text { to } \\
\$ 1.76 \text { per employee per hour } \\
\text { depending on the number of full-time } \\
\text { employees. An employer has several } \\
\text { options for meeting its "health care } \\
\text { expenditure” requirement. In addition } \\
\text { to contributing in some way to } \\
\text { payment for health care services or } \\
\text { insurance, the employer has the option } \\
\text { of paying its required expenditure to } \\
\text { the city. Amounts paid to the city will } \\
\text { fund the Health Access Program, } \\
\text { which aims to provide medical care to } \\
\text { the uninsured population of San } \\
\text { Francisco. }\end{array}$ \\
\hline $\begin{array}{l}\text { What is the } \\
\text { law's } \\
\text { purpose? }\end{array}$ & $\begin{array}{l}\text { Maryland was attempting to address the } \\
\text { rising cost of Medicaid and the high } \\
\text { proportion of uninsured people in the state. } \\
\text { Legislative history indicates that legislators } \\
\text { understood the Act as requiring Wal-Mart } \\
\text { (the only company to which the act applied) } \\
\text { to increase its healthcare spending. The } \\
\text { statute was specifically designed only to } \\
\text { apply to Wal-Mart. }\end{array}$ & $\begin{array}{l}\text { Provide access to care for uninsured } \\
\text { adults living in the city of San } \\
\text { Francisco who do not qualify for } \\
\text { coverage under Medicaid. }\end{array}$ \\
\hline $\begin{array}{l}\text { What } \\
\text { employers } \\
\text { are covered? }\end{array}$ & $\begin{array}{l}\text { Employers with more than 10,000 } \\
\text { employees (NOTE: only four employers in } \\
\text { the state met this number - Johns Hopkins } \\
\text { University, Northrop Grumman, Giant } \\
\text { Food, and Wal-Mart. However, the law } \\
\text { only applied to Wal-Mart because Johns } \\
\text { Hopkins met the lesser requirement for non- } \\
\text { profits and Northrop Grumman and Giant } \\
\text { Food spent enough on health care to be } \\
\text { exempt). }\end{array}$ & $\begin{array}{l}\text { Under the Employer Spending } \\
\text { Requirement, for-profit employers with } \\
\text { more than } 20 \text { employees and non-profit } \\
\text { employers with more than } 50 \\
\text { employees. }\end{array}$ \\
\hline $\begin{array}{l}\text { Amount of } \\
\text { employer } \\
\text { contribution? }\end{array}$ & $\begin{array}{l}\text { For-profit employers were required to either } \\
\text { 1.) spend at least } 8 \% \text { of their payroll on } \\
\text { health benefits or } 2 \text {.) pay the difference } \\
\text { directly into the state's newly created public } \\
\text { health care fund to defray Medicaid costs. } \\
\text { Covered non-profit employers were required } \\
\text { to spend } 6 \% \text { of their payroll on health } \\
\text { benefits. }\end{array}$ & $\begin{array}{l}\text { Covered employers must contribute } \\
\$ 1.17 \text { to } \$ 1.76 \text { per hour per employee } \\
\text { toward "health care expenditures.” }\end{array}$ \\
\hline $\begin{array}{l}\text { What options } \\
\text { do employers } \\
\text { have under } \\
\text { the law? }\end{array}$ & $\begin{array}{l}\text { "Health insurance costs" defined as any } \\
\text { amount paid by an employer to provide } \\
\text { health care or health insurance to employees } \\
\text { to the extent costs may be deductible under }\end{array}$ & $\begin{array}{l}\text { Health care expenditure" is defined as } \\
\text { any amount paid by a covered } \\
\text { employer to its employees or a third } \\
\text { party on behalf of its employees for the }\end{array}$ \\
\hline
\end{tabular}

O’NEILL INSTITUTE FOR NATIONAL AND GLOBAL HEALTH LAW

GEORGETOWN LAW | 600 NEW JERSEY AVENUE NW | WASHINGTON, DC 20001 www.oneillinstitute.org 


\begin{tabular}{|c|c|c|}
\hline & $\begin{array}{l}\text { federal tax law. Expenditures that could } \\
\text { qualify as “health insurance costs” included: } \\
\text { - } \\
\text { Maintenance of on-site medical } \\
\text { clinics. } \\
\text { - Contribution to employees' Health } \\
\text { Savings Accounts. } \\
\text { - } \quad \text { Payment for medical care, } \\
\text { prescription drugs, or vision care. } \\
\text { - } \quad \text { Restructure of employee benefits } \\
\text { plans to increase amount paid } \\
\text { toward insurance. } \\
\text { - Any other costs to provide health } \\
\text { benefits.” } \\
\text { An employer also had the option of paying } \\
\text { the difference of what the employer } \\
\text { contributed in health care expenditures and } \\
\text { the 8\% requirement into the Maryland Fair } \\
\text { Share Fund. }\end{array}$ & 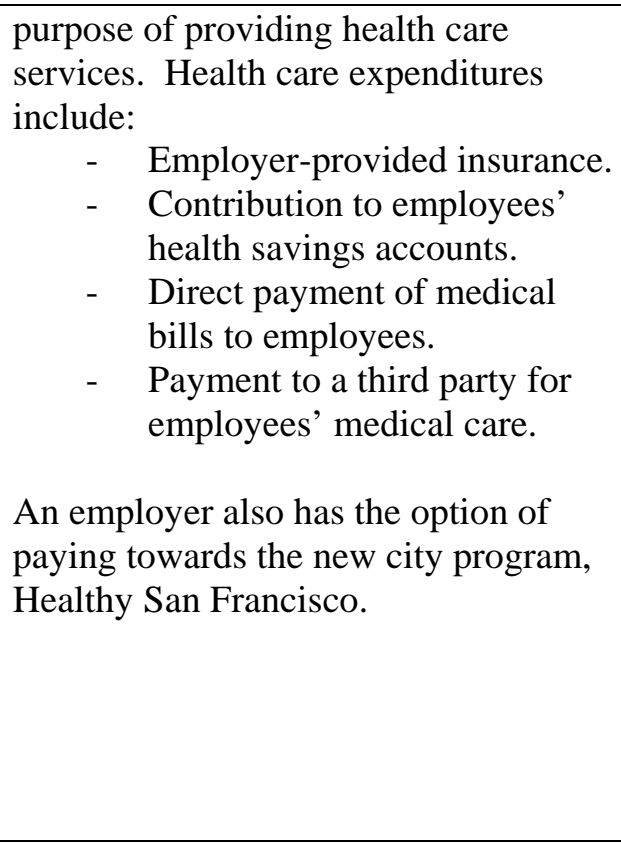 \\
\hline $\begin{array}{l}\text { Are there } \\
\text { reporting } \\
\text { requirements } \\
\text { under the } \\
\text { law? }\end{array}$ & $\begin{array}{l}\text { Yes. Covered employer must make annual } \\
\text { reports providing the amount spent by the } \\
\text { employer on health insurance costs in the } \\
\text { state, and the percentage of payroll that was } \\
\text { spent by the employer on health insurance } \\
\text { costs in the state. }\end{array}$ & $\begin{array}{l}\text { Yes. Covered employers must report } \\
\text { on their health care expenditures on an } \\
\text { annual basis using the "Mandatory } \\
\text { Annual Reporting Form" provided to } \\
\text { all registered businesses in San } \\
\text { Francisco. }\end{array}$ \\
\hline
\end{tabular}

O’NEILL INSTITUTE FOR NATIONAL AND GLOBAL HEALTH LAW

GEORGETOWN LAW | 600 NEW JERSEY AVENUE NW | WASHINGTON, DC 20001

www.oneillinstitute.org 
${ }^{1}$ Professor of Health Law and Policy, and Director, Center for Law, Ethics, and Health, University of Michigan School of Public Health. I would like to thank his advisory group members: Stephanie Kanwit, JD (Special Counsel \& Healthcare Consultant for America's Health Insurance Plans), Elizabeth Leonard, JD (Associate Professor University of Kansas School of Law), and Patricia Butler, JD, DrPH (Health Policy Analyst) for their feedback and assistance. I would also like to thank Sandy H. Han and Amy E. Killelea for their excellent research assistance. I also want to thank the O'Neill Institute for its generous financial and research support.

${ }^{2}$ In the same way, states can impede local jurisdictions from enacting ordinances or regulations (i.e., tobacco control).

${ }^{3}$ Subcommittee on Labor of the Committee on Labor and Public Welfare, United States Senate, Legislative History of the Employee Retirement Income Security Act of 1974 (Washington D.C.: U.S. Gov't Print Office, 1976): at 3456. ${ }^{4}$ ERISA covers self-funded (or self-insured plans where the employer provides health benefits directly to employees (plan participants). It does not cover health insurance that an individual employee purchases in the commercial market. Generally, small employers (with under 100 employees) do not offer self-funded plans. See, e.g., J. Stayman, "Regulation of Health Benefits Under ERISA: An Outline”, Congressional Research Service, Order Code RS22643, April 12, 2007 available at http://opencrs.com/document/RS22643 (last visited Jan. 12, 2009).

${ }^{5}$ Nealy v. U.S. Healthcare, 711 N.E.2d 621 (N.Y. 1999). In deciding ERISA preemption cases, courts interpret two sections of the law-514 and 502(a). A case could be preempted under either section. Section 514 has been labeled as field preemption in the judicial opinions. Basically, it amounts to the interaction between the "relates to," savings, and deemer clauses. If the state law conflicts with these provisions, it will be preempted. Section 502(a) is called complete preemption. This section allows an insurer to remove the case to federal court even if the plaintiff has not mentioned ERISA in the complaint. Section 502(a) also limits the available remedies to the amount of the benefit. No punitive or consequential damages can be recovered.

${ }^{6}$ K. A. Jordan, “Travelers Insurance: New Support for the Argument to Restrain ERISA Preemption,” Yale Journal on Regulation, 13 (1996): 255-336.

${ }^{7}$ P.D. Jacobson and S.D. Pomfret, "Form, Function, and Managed Care Torts: Achieving fairness and equity in ERISA jurisprudence,” Houston Law Review, 35, no. 4 (1998): 985-1078.

${ }^{8}$ Moreno v. Health Partners Health Plan, 4 F. Supp.2d 888 (D.Ariz. 1998).

${ }^{9} 29$ U.S.C. Art. 1132 (2008).

${ }^{10}$ McEvoy v. Group Health Cooperative of Eau Claire, 570 N.W.2d 397 (Wis. 1997).

1129 U.S.C. § 1104 (a)(1) (2008).

${ }^{12}$ Kyle Railways, Inc. v. Pacific Administration Services, 990 F.2d 513 (9th Cir. 1993).

${ }^{13}$ Reilly v. Blue Cross and Blue Shield United of Wisconsin, 846 F.2d 416 (7th Cir. 1988).

${ }^{14}$ Curtiss-Wright Corp. v. Schoonejongen, 115 S.Ct. 1223, 1228 (1995); Maltz v. Aetna Health Plans of New York, 114 F.3d 9, 12 (2d Cir. 1997).

${ }^{15}$ Firestone Tire \& Rubber Co. v. Bruch, 489 U.S. 101 (1989). See also, Pegram v. Herdrich 530 U.S. 211 (2000); Metropolitan Life Insurance Co. v. Glenn, 128 S.Ct. 2343 (2008).

${ }^{16}$ McGraw v. Prudential Insurance Co., 1998 WL 96849 (10th Cir. 1998); E.H. Morreim, "Benefits Decisions in ERISA plans: Diminishing Deference to Fiduciaries and an Emerging Problem for Provider-Sponsored Organizations,” Tennessee Law Review, 65 (1998): 511-553.

${ }^{17}$ England v. John Alden Life Ins. Co., 846 F.Supp. 798, 801 (W.D. Missouri 1994).

${ }^{18}$ Metropolitan Life Insurance Co. v. Glenn, 128 S.Ct. 2343 (2008). After reconfirming the four factors to balance from the Firestone case, the Court stated that "The conflict of interest ...should prove more important (perhaps of great importance) where circumstances suggest a higher likelihood that it affected the benefits decision, including, but not limited to, cases where an insurance company administrator has a history of biased claims administration," at 2352.

${ }^{19}$ This is not to suggest that the cases are necessarily mutually reinforcing. Instead, as Elizabeth Weeks notes, Art. 514 (the three preemption provisions) operates separately from Art. 502 (the limited remedies section), but they both may apply or overlap in some cases. Personal communication from Elizabeth Weeks to author (Nov. 12, 2008).

${ }^{20}$ Compare, for instance, Edward Zelinsky's analysis that ERISA would preempt most of the provisions of the Massachusetts health reform program with Patricia Butler's more optimistic assessment that properly designed state reforms could surmount an ERISA preemption challenge. E.A. Zelinsky, "The New Massachusetts Health Law: Preemption and Experimentation,” William \& Mary Law Review, 49 (2007): 229-287; E.A. Zelinsky, "Employer Mandates and ERISA Preemption: A Critique of Golden Gate Restaurant Association v. San Francisco," Cardozo School of Law, Working Paper No. 246, November 2008; P.A. Butler, "ERISA Implications for State Health Care Access Initiatives: Impact of the Maryland "Fair Share Act" Court Decision," National Academy for State Health Policy, 2006, available at http://www.nashp.org/Files/ERISA_Implications.pdf (last visited Jan. 12, 2009). See

O’NEILL INSTITUTE FOR NATIONAL AND GLOBAL HEALTH LAW GEORGETOWN LAW | 600 NEW JERSEY AVENUE NW | WASHINGTON, DC 20001 www.oneillinstitute.org 
also, K.B. Polvino, M.K. Antia, and J.P. Burnette, "ERISA as an Obstacle to Fair Share Legislation and Other State Initiatives to Expand Coverage to the Uninsured and Underinsured,” Journal of Health \& Life Sciences Law, 1 (2007): 99-126; J.O. Shimabukuro and J. Staman, "Legal Issues Relating to State Health Care Regulation: ERISA Preemption and Fair Share Laws," Congressional Research Service, Order Code RL34637, Aug. 28, 2008 available at http://opencrs.com/document/RL34637 (last visited Jan. 12, 2009).

${ }^{21}$ Shaw v. Delta Airlines, Inc., 463 U.S. 85 (1983); Metropolitan Life Insurance Co. v. Massachusetts, 471 U.S. 724 (1985) Pilot Life v. Dedeaux, 481 U.S. 41 (1987).

${ }^{22}$ Shaw v. Delta Airlines, Inc, 463 U.S. 85 (1983).

${ }^{23}$ Along with many others, I have been harshly critical of how these cases were resolved. Now is not the time to revisit those arguments, but the reader can review the arguments in P.D. Jacobson and S.D. Pomfret, "Form, Function, and Managed Care Torts: Achieving fairness and equity in ERISA jurisprudence,” Houston Law Review, 35 (1998): 985-1078 Among similar analyses cited in that article, see K.L. Butler, "Securing Health Benefits Through ERISA and the ADA,” Emory Law Journal, 43 no. 4, (1993):1197-1243; C.L. Fisk, The Last Articles About the Language of ERISA Preemption? A Case Study of the Failure of Textualism, Harvard Journal on Legislation, 33 (1996): 35-104; M.G. Farrell, "ERISA Preemption and Regulation of Managed Health Care: The Case for Managed Federalism,” American Journal of Law \& Medicine, 23 (1997): 251-290.

${ }^{24}$ See Jacobson and Pomfret, supra note 7 at 1010-1011.

${ }^{25}$ Jacobson and Pomfret, supra note 7. It is fair to say that not everyone agrees with this interpretation of the legislative history. Two reviewers note that three floor statements mention the preemption clause as applying to EBPs, along with congressional concern about a Missouri proposal to tax self-insured employer health care and the CA Knox-Keene law that would have applied extensive managed care standards to self-insured employer plans. Nevertheless, the floor debate was overwhelmingly devoted to the pension aspects and did not contemplate the ways in which health care was transformed in the 1980s and 1990s.

${ }^{26}$ California Division of Labor Standards Enforcement v. Dillingham Construction, Inc., 519 U.S. 316 (1997), at 335 (Scalia, J., concurring). In Aetna Health, Inc. v. Davila, 542 U.S. 200, 222 (2004), Justice Ginsburg went much further, stating that "I also join the "rising judicial chorus urging that Congress and [theis] Court revisit what is an unjust and increasingly tangled ERISA regime’” (citing DiFelice v. Aetna U.S. Healthcare, 346 F.3d 442, 453, 3d Cir. 2003).

${ }^{27} 514$ U.S. 645 (1995).

${ }^{28} 536$ U.S. 355 (2002).

${ }^{29} 538$ U.S. 329 (2003).

${ }^{30}$ Physicians have supported AWP laws because they limit health plans' ability to exclude physicians from their patient population. Plans have opposed them on the grounds that these laws inhibit valuable quality of care controls. ${ }^{31} 57$ F.3d 350 (3d Cir. 1995). This case is also notable because it fails to grapple with the meaning of important ERISA terms such as benefit and plan, despite the plaintiff's direct attempt to distinguish between the plan (EBP) and the MCO. For more detail, see Jacobson and Pomfret, supra note 7 at 1031; R. Korobkin, "The Failed Jurisprudence of Managed Care, and How to Fix It: Reinterpreting ERISA Preemption,” UCLA Law Review, 51 no. 2 (2003): 457-538.

32530 U.S. 211 (2000).

${ }^{33}$ M.G. Bloche and P.D. Jacobson, “The Supreme Court and Bedside Rationing,” JAMA 2000; 284:2776-2779.

${ }^{34}$ Aetna Health, Inc. v. Davila, 542 U.S. 200 (2004). In this case, the Court takes a broad reading of Art. 502's exclusive remedy to preempt even a state law that appears to be consistent with ERISA.

${ }^{35}$ In Metropolitan Life Insurance Co. v. Glenn, supra note 19, the Court ruled that a plan's conflict of interest in resolving a participant's challenge to a coverage denial is one factor to be considered in determining whether the plan met its fiduciary duty.

${ }^{36}$ Quality Infusion Care, Inc. v. Humana Health Plan of Texas Inc., No. 07-20703, 2008 WL 3471861 (5th Cir. Aug. 13, 2008).

${ }^{37}$ See, e.g., Barber v. Unum Life Insurance Co. of America, 383 F.3d 134 ( $3^{\text {rd }}$ Cir. 2004).

${ }^{38}$ See, e.g., American Council of Life Insurers v. Watters, 536 F. Supp. 2d 811 (W.D. Mich. 2008); Standard Insurance Co. v. Morrison, 537 F. Supp. 2d 1142 (D. Mont. 2008).

${ }^{39}$ A third issue of potential interest is whether ERISA preemption would affect laws permitting the purchase of health insurance across state lines. Stephanie Kanwit is addressing these issues in another Legal Solutions in Health Reform paper on Purchasing Insurance Across State Lines.

${ }^{40} 475$ F.3d 180 (4th Cir. 2007). In this case, the court preempted Pennsylvania's bad faith insurance law because it provided a remedy outside of Section 502 and did not affect the risk-pooling arrangement that Miller requires.

41497 F. Supp. 2d 403 (E.D.N.Y. 2007).

42546 F.3d 639 (9th Cir. 2008).

O’NEILl INSTITUTE FOR NATIONAL AND GLOBAL HEALTH LAW GEORGETOWN LAW | 600 NEW JERSEY AVENUE NW | WASHINGTON, DC 20001 www.oneillinstitute.org 
${ }^{43}$ Id. at 646-47.

${ }^{44}$ In rejecting the argument that the ordinance makes reference to an EBP, the court cited cases refusing to preempt statutes requiring employers to provide workers' compensation benefits or prevailing wages. See, e.g., California Division of Labor Standards Enforcement v. Dillingham Construction, Inc., 519 U.S. 316 (1997); WSB Elec., Inc. v. Curry, 88 F.3d 788 ( $9^{\text {th }}$ Cir. 1996); and District of Columbia v. Greater Washington Board of trade, 506 U.S. 125 (1992).

${ }^{45}$ Golden Gate Restaurant Ass'n v. City and County of San Francisco, 546 F.3d 639, 660 (9th Circuit 2008).

${ }^{46}$ See also, C.L. Fisk and M.M. Oswalt, "Preemption and Civic democracy in the Battle Over Wal-Mart," Minnesota Law Review, 92 (2008): 1502-1538. Fisk and Oswalt agree with Butler's analysis and argue that ERISA preemption undermines the democratic debate over appropriate health reform legislation; P.A. Butler, "ERISA Implications for State Health Care Access Initiatives: Impact of the Maryland "Fair Share Act” Court Decision," National Academy for State Health Policy, 2006, available at http://www.nashp.org/Files/ERISA_Implications.pdf (last visited Jan. 12, 2009).

${ }^{47}$ E.A. Zelinsky, “The New Massachusetts Health Law: Preemption and Experimentation,” William \& Mary Law Review, 49 (2007): 229-287, at 276.

${ }^{48}$ Id. with Zelinky citing Egelhoff case.

${ }^{49}$ Personal communication from Pat Butler to author (Sept. 25, 2008).

50 See, e.g., Grimo v. Blue Cross/Blue Shield of Vermont, 34 F.3d 148, 151 (2nd Cir. 1994); International Resources Inc. v. New York Life Ins. Co., 950 F.2d 294, 297 (6th Cir. 1991). As Polvino et al. note in a different context, the ERISA plans remain the purchasers of services, not the individuals subject to the mandate (at p. 113). See also, Fort Halifax Packing Co., Inc. v. Coyne, 482 U.S. 1 (1987); and Massachusetts v. Morash, 490 U.S. 107 (1989).

${ }^{51}$ Personal communication from Pat Butler to author (Sept. 25, 2008).

52 C.F.R. Art. 2510.3-1(j) (2007).

${ }^{53}$ For more elaboration of these themes, see P.D. Jacobson and E. Selvin, "Health, Inequality, and the Courts," in J.A. Morone and L.R. Jacobs, eds., Healthy, Wealthy \& Fair: Health Care and the Good Society, (Oxford University Press, 2005): 235-264.

${ }^{54}$ For a broad normative argument against preemption based on principles of civic democracy and local control, see Fisk and Oswalt, supra note $\mathrm{l}$ at 1533-1538.

${ }^{55}$ See, e.g., S.M. Butler, Think Small, New York Times Campaign Stops Blog, available at http://campaignstops.blogs.nytimes.com/11/16/think-small/ (last visited November 16, 2008).

${ }^{56}$ See, e.g., Rice v. Panchal, 65 F.3d 637 (7th Cir. 1995).

${ }^{57}$ See, e.g., Jacobson and Pomfret, supra note 7; and Korobkin, supra note 35.

${ }^{58}$ Fort Halifax Packing Co., Inc. v. Coyne, 482 U.S. 1 (1987).

${ }^{59}$ My hypothesis is that this is a major cause of current physician liability exposure and hence rising physician medical insurance liability premiums.

6029 U.S.C. Art. 1002(1) (2008).

${ }^{61}$ Professor Korobkin proposes that the Supreme Court should reverse its decision to include MCOs as plan benefits and rule instead that ERISA was not intended to "govern the relationships between employees and third parties, such as MCOs.” Korobkin, supra note 35 at 60.

${ }^{62}$ For instance, Elizabeth Weeks argues that a better way to analyze the cases is to distinguish whether the case raises Art. 514 or Art. 502 issues (or both). Professor Weeks argues that the consistency in the litigation is that 502 always trumps 514. Even if, therefore, a state law would be saved from preemption under 514, it is still preempted if 502 applies. One problem with this analysis is the inherent subjectivity of when 502 should apply. Personal Communication from Elizabeth Weeks to author (Nov. 12, 2008).

O’NEILL INSTITUTE FOR NATIONAL AND GLOBAL HEALTH LAW 